\title{
Debt Relief and Debtor Outcomes: Measuring the Effects of Consumer Bankruptcy Protection Online Appendix
}

Will Dobbie

Princeton University and NBER
Jae Song

Social Security Administration 
Appendix Figure 1

The Geography of Consumer Bankruptcy

Number of Bankruptcy Offices in Each Court
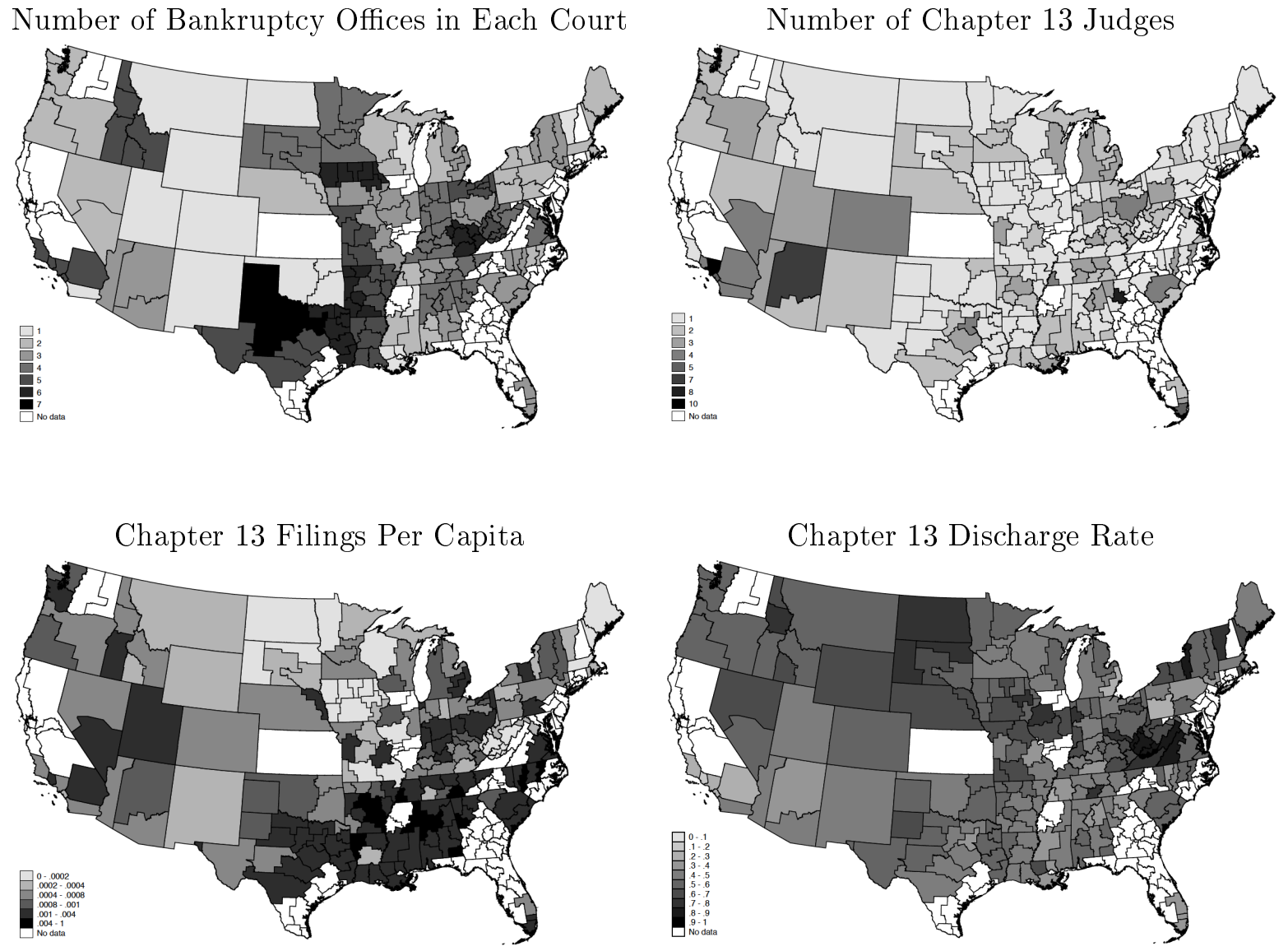

Variation in Chapter 13 Judge Leniency

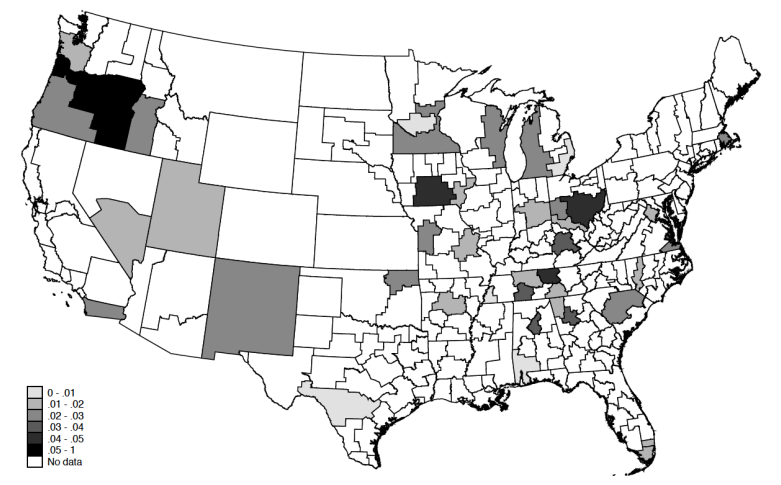

Notes: These figures display summary statistics by bankruptcy office. The sample includes the 72 bankruptcy courts that allow electronic access to their dockets. The number of Chapter 13 judges is based on 2003 filings. Per capita Chapter 13 filings are calculated using the average annual number of filings between 2000 and 2004 divided by population as reported by the 2000 census. The Chapter 13 discharge rate is calculated across all available years between 1992 and 2005. The Chapter 13 judge leniency sample includes all first-time filings between 1992 and 2005 in the 42 offices that randomly assign cases to judges. 
Appendix Figure 2

Distribution of Judge by Office Observations



Notes: This figure displays the distribution of judge by office cell sizes in our estimation sample. The sample consists of all first-time filers between 1992 and 2005 in the 42 offices that randomly assign filings to judges. See text for details. 
Appendix Figure 3

Distribution of Chapter 13 Judge Leniency



Notes: This figure displays the distribution of Chapter 13 judge leniency for the estimation sample. The sample consists of all first-time filers between 1992 and 2005 in the 42 offices that randomly assign filings to judges. Judge leniency is defined as the leave-one-out mean rate of granting bankruptcy protection for the assigned judge minus the leave-one-out mean rate of granting bankruptcy protection for the office in the same filing year. 
Appendix Figure 4

Persistence of Chapter 13 Judge Discharge Rates



Notes: This figure shows the correlation between judge specific Chapter 13 discharge rates in the current and lagged years. The sample consists of all first-time filers between 1992 and 2005 in the 42 offices that randomly assign filings to judges. See text for details. 
Appendix Figure 5

Chapter 13 Judge Leniency by Filer Characteristics

Male vs. Female



High vs. Low Earnings

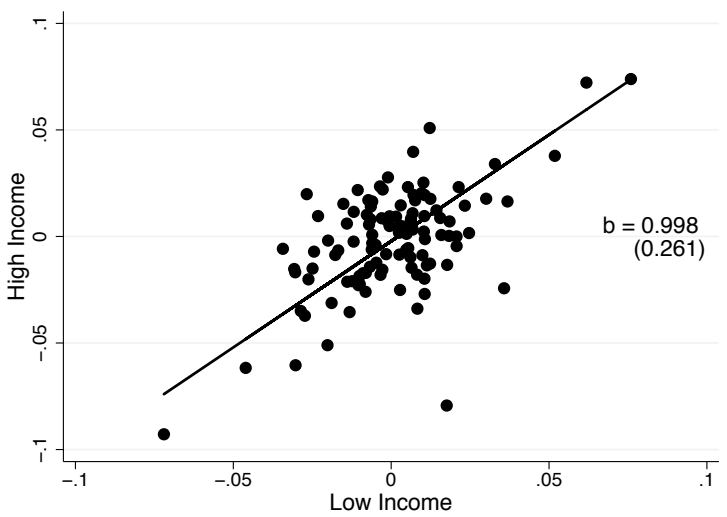

White vs. Non-White



Over vs. Under 40

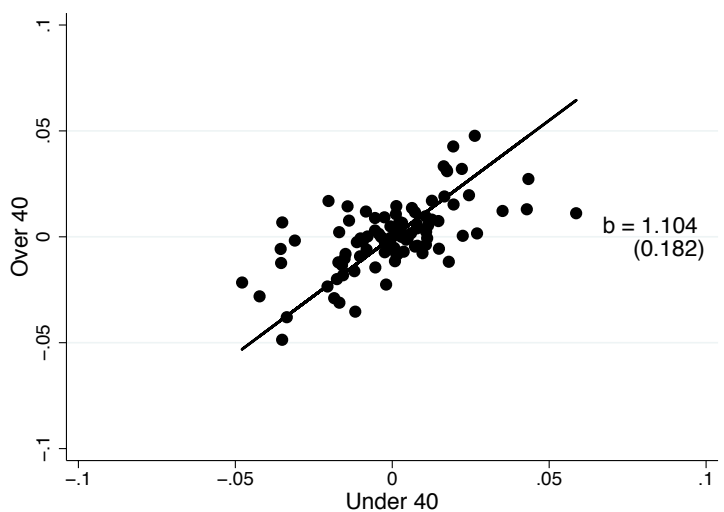

Matched to Home vs. Not Matched

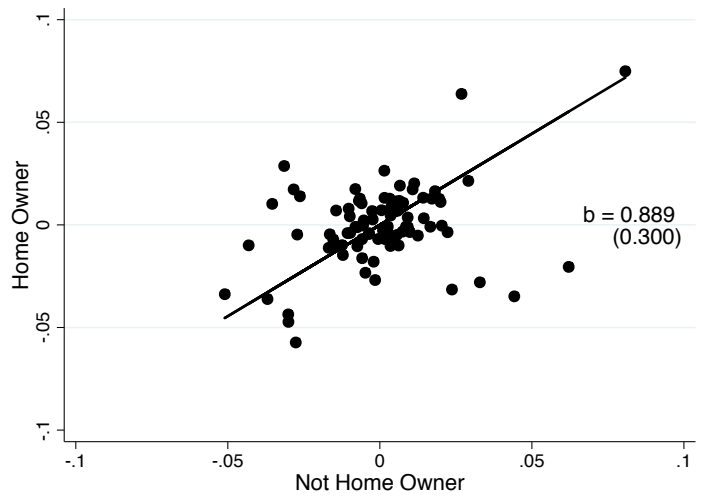

Notes: These figures show the correlation between judge leniency for different groups of filers. The sample consists of all first-time filers between 1992 and 2005 in the 42 offices that randomly assign filings to judges. Judge leniency is defined as the leave-one-out mean rate of granting bankruptcy protection for the assigned judge minus the leave-oneout mean rate of granting bankruptcy protection for the office in the same filing year. We take the average leniency for each group over all available years of data. The solid line shows the best linear fit estimated using OLS relating each judge leniency measure. 
Appendix Figure 6

Mean and Median Earnings for Granted and Dismissed Chapter 13 Filers
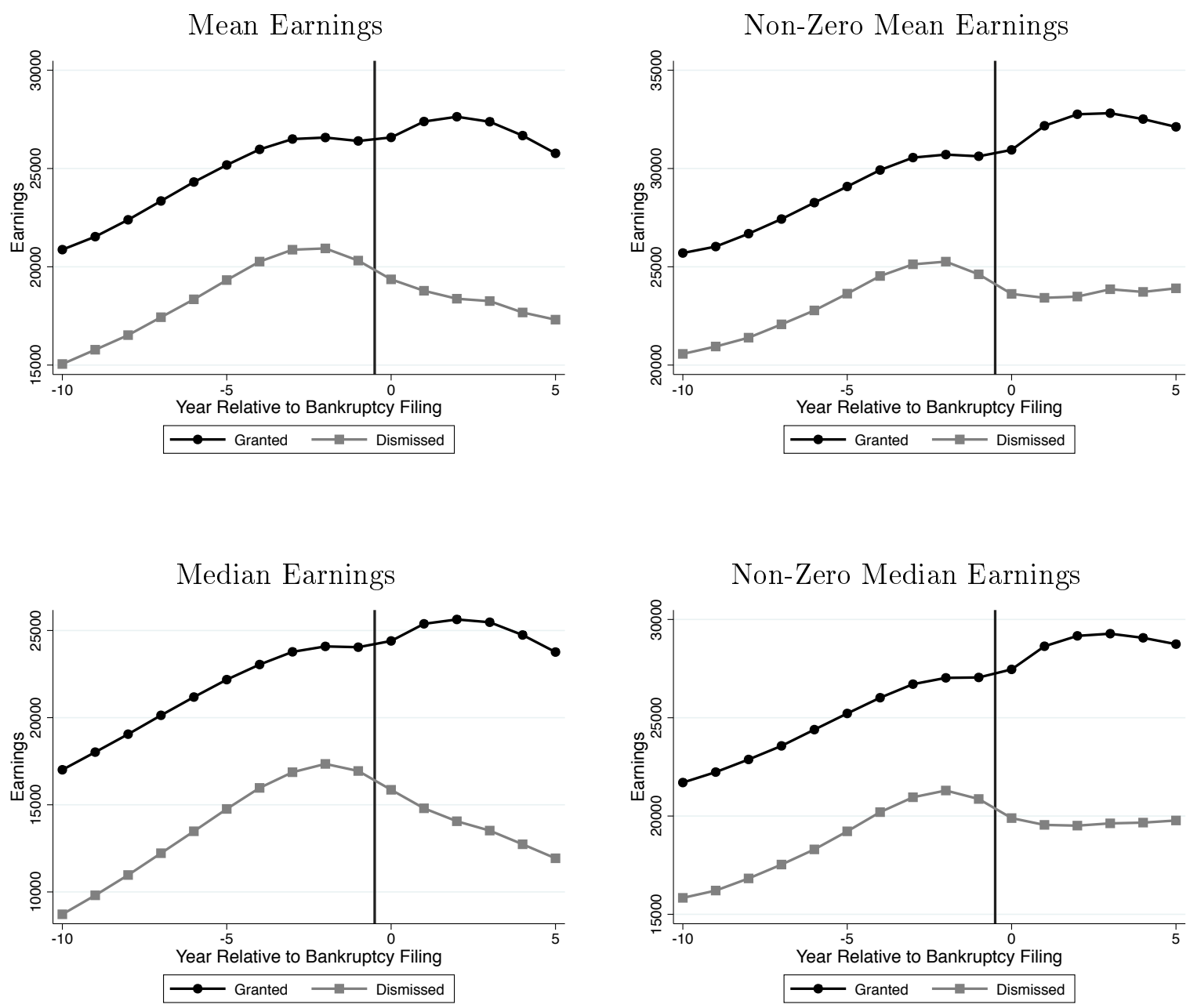

Notes: These figures plot mean and median earnings for granted and dismissed bankruptcy filers. The sample includes all first-time filings between 1992 and 2005 in the 42 offices that randomly assign cases to judges. Year 0 indicates the year a debtor files for bankruptcy protection. See text for additional details. 
Appendix Figure 7

401k Contributions, Disability Insurance, and Supplemental Security Income for Granted and Dismissed Chapter 13 Filers

401k Contributions

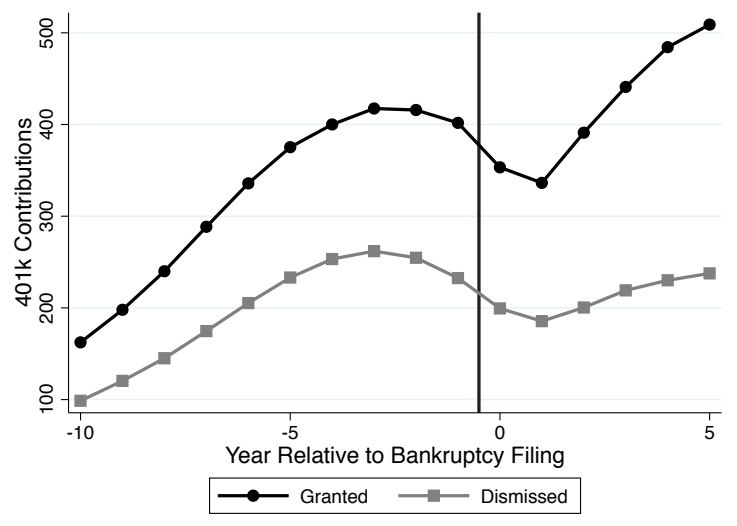

Disability Insurance

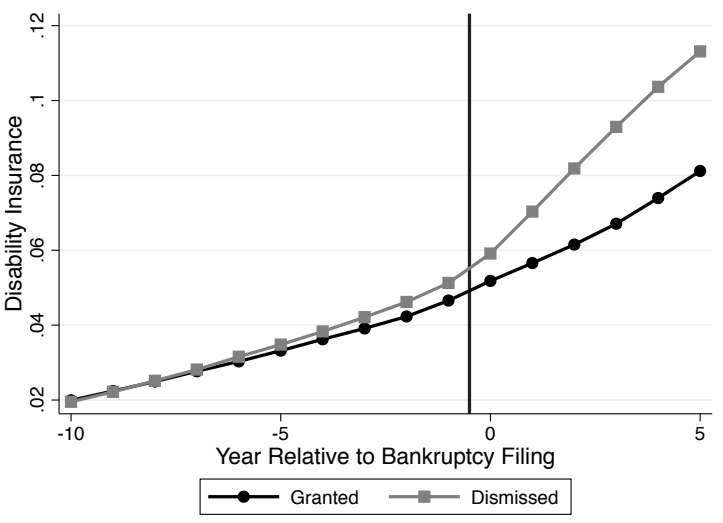

Sup. Security Income



Notes: These figures plot average $401 \mathrm{k}$ contributions, Disability Insurance, and Sup. Security Income for granted and dismissed bankruptcy filers. The sample includes all first-time filings between 1992 and 2005 in the 42 offices that randomly assign cases to judges. The Sup. Security Income sample includes the subset of filers 65 or older. Year 0 indicates the year a debtor files for bankruptcy protection. 
Appendix Figure 8

Chapter 13 Judge Leniency and 401k Contributions,

Disability Insurance, and Supplemental Security Income

401k Contributions

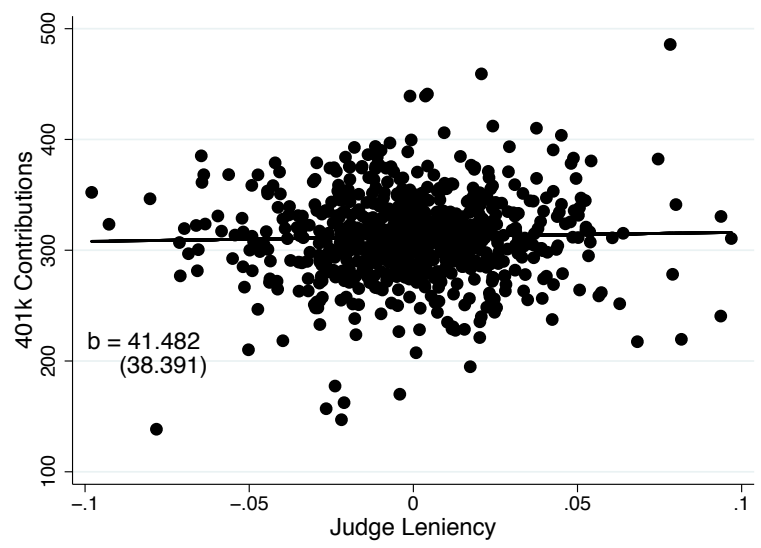

Disability Insurance

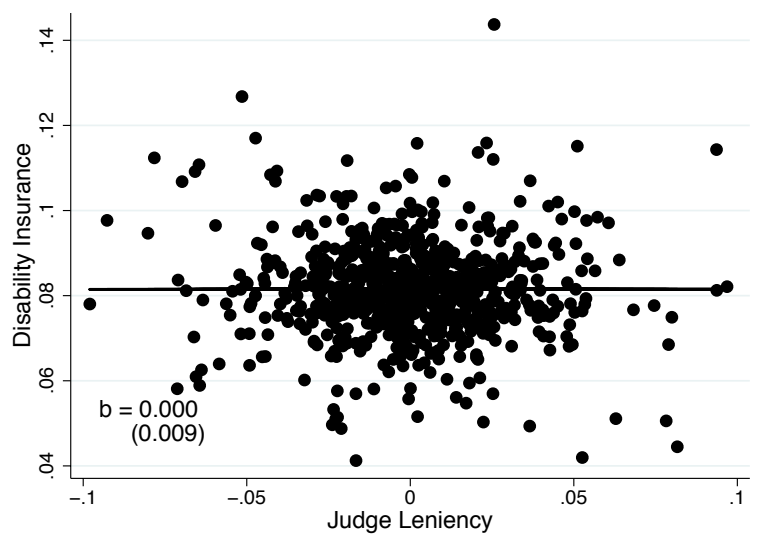

Sup. Security Income

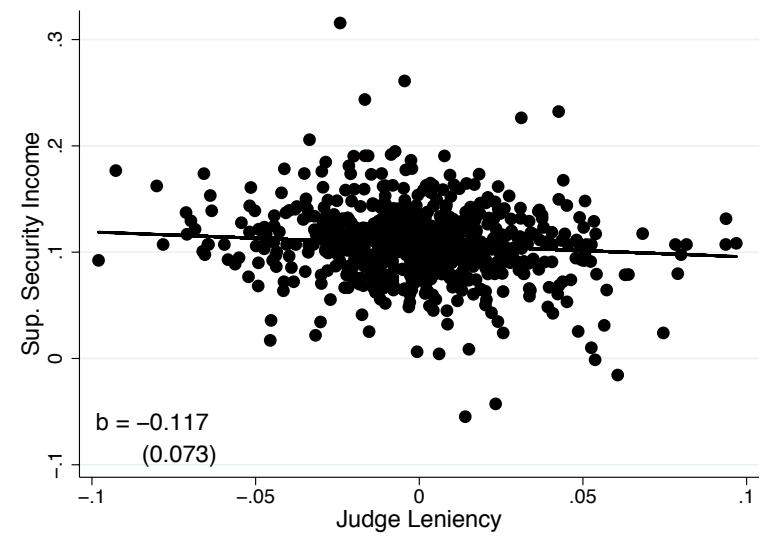

Notes: These figures plot 401k contributions, Disability Insurance, and Sup. Security Income vs. our leave-one-out measure of judge leniency. The sample includes all first-time filings between 1992 and 2005 in the 42 offices that randomly assign cases to judges. The Sup. Security Income sample includes the subset of filers 65 or older. Judge leniency is the leave-one-out mean rate of granting Chapter 13 bankruptcy protection for the assigned judge minus the leave-one-out mean rate of granting bankruptcy protection for the court in the same filing year. To construct the binned scatter plot, we first regress each outcome on office by month-of-filing fixed effects and calculate residuals. We then take the mean residual in each judge by year bin, adding the mean discharge rate to each residual to aid in the interpretation of the plot. The solid line shows the best linear fit estimated on the underlying micro data estimated using OLS. The coefficients show the estimated slope of the best-fit line including office by month-of-filing fixed effects, with standard errors clustered at the office level reported in parentheses. 


\section{Appendix Figure 9}

IV Estimates of the Impact of Chapter 13 Protection on

401k Contributions, Disability Insurance, and Supplemental Security Income

401k Contributions

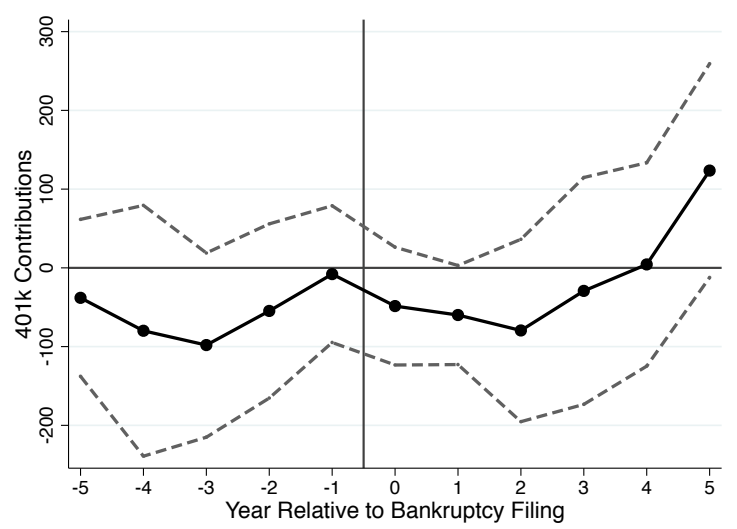

Disability Insurance

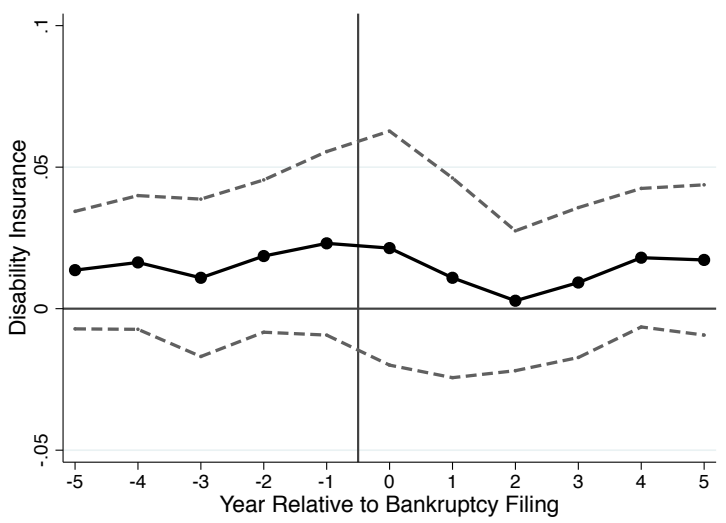

Sup. Security Income



Notes: These figures plot two-stage least squares results of the impact of Chapter 13 bankruptcy protection. The earnings and mortality sample includes all first-time filings between 1992 and 2005 in the 42 offices that randomly assign cases to judges. The Sup. Security Income sample includes the subset of filers 65 or older. We instrument for bankruptcy protection using judge leniency and control for gender, race, five-year age effects, baseline employment, baseline earnings, and office by month-of-filing fixed effects. The dashed lines are 95 percent confidence intervals from standard errors clustered at the office level. Year 0 indicates the year a debtor files for bankruptcy protection. 
Appendix Figure 10

Job Mobility Outcomes for Granted and Dismissed Chapter 13 Filers
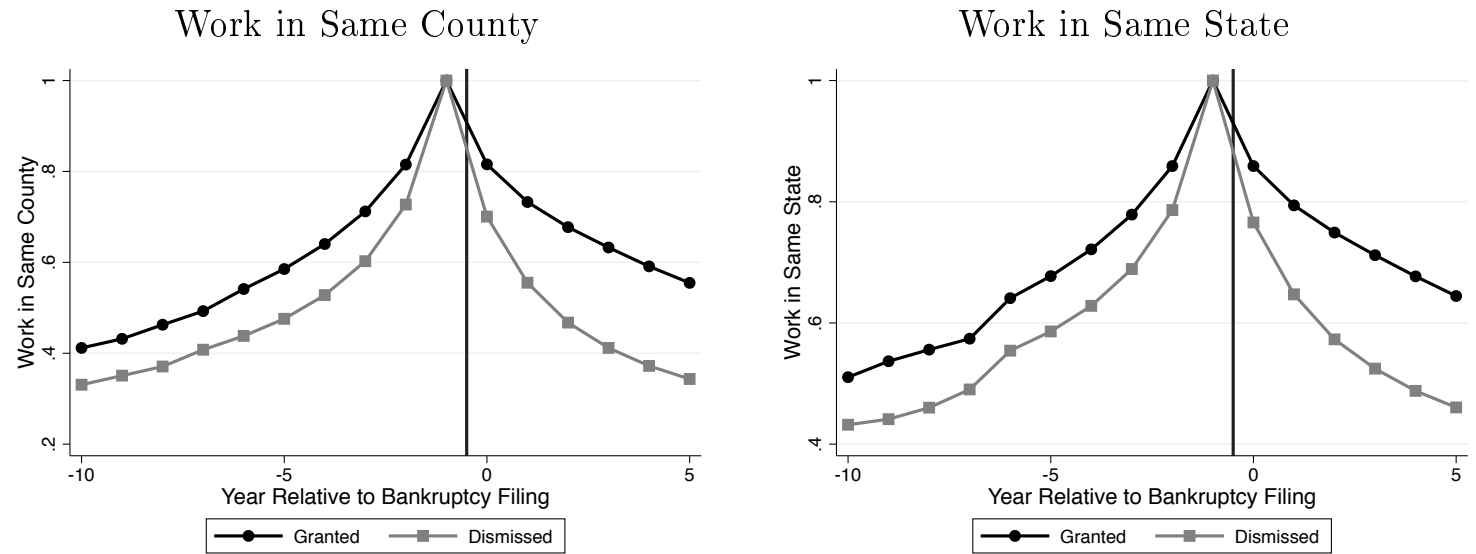

Work in Same Job

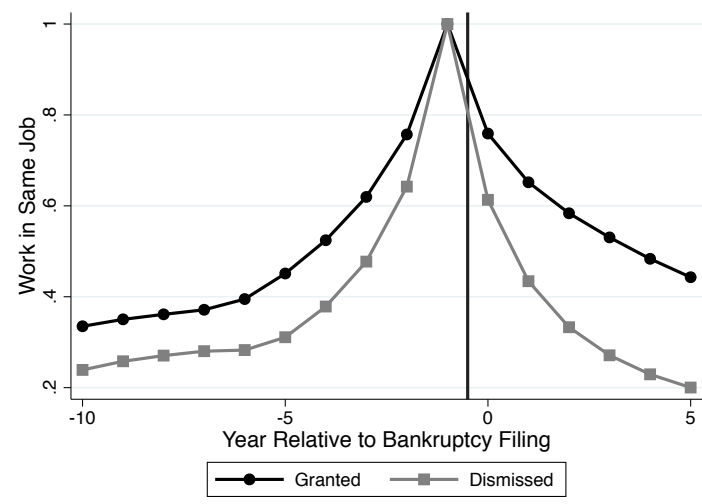

Work in Same Industry

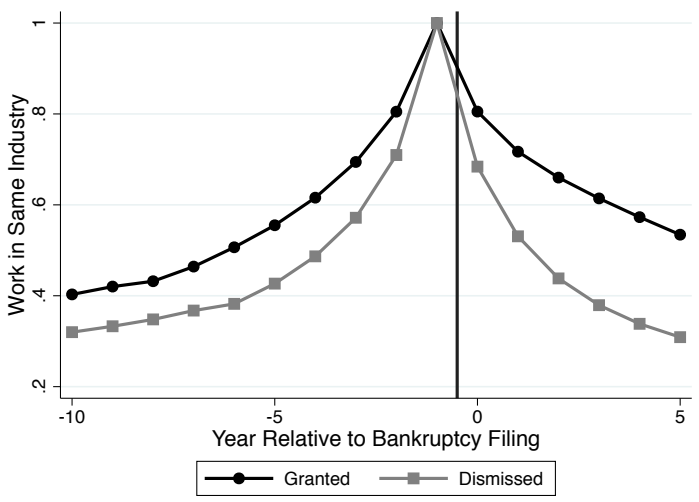

Job Tenure

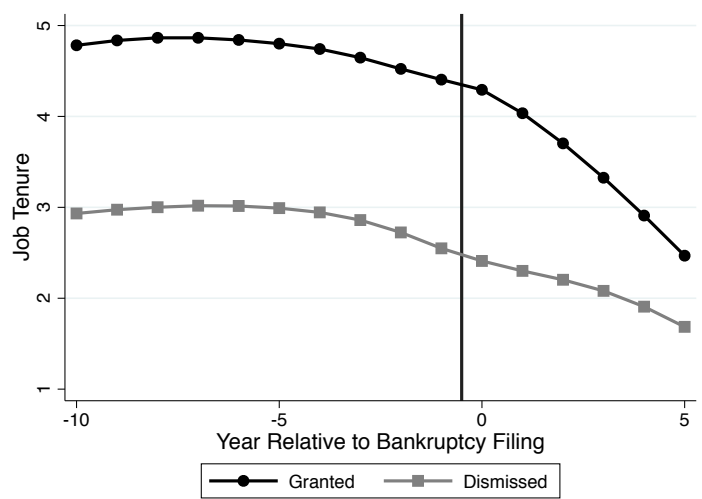

Work in Firm Wages

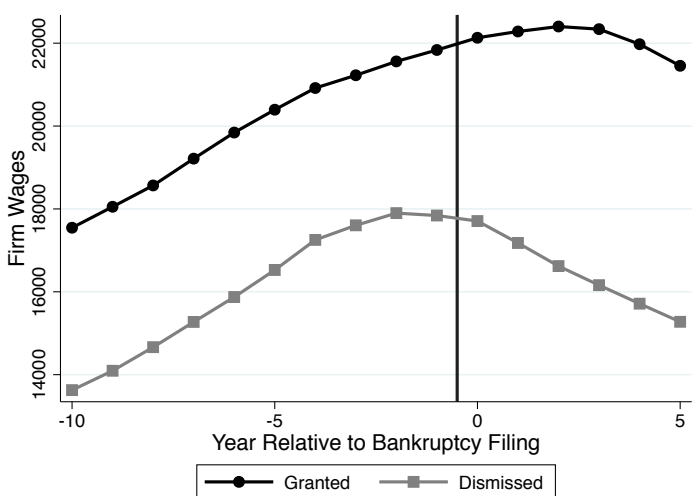

Notes: These figures plot average job mobility outcomes for granted and dismissed bankruptcy filers. The sample includes all first-time filings between 1992 and 2005 in the 42 offices that randomly assign cases to judges that are employed for at least one time period post-bankruptcy. Year 0 indicates the year a debtor files for bankruptcy protection. Same county, state, job, and industry variables are defined relative to the year before filing. Each variable is therefore mechanically equal to one in year -1 . See Table 7 for additional details. 
Marginal Treatment Effects for Labor Supply, Mortality, and Home Foreclosure
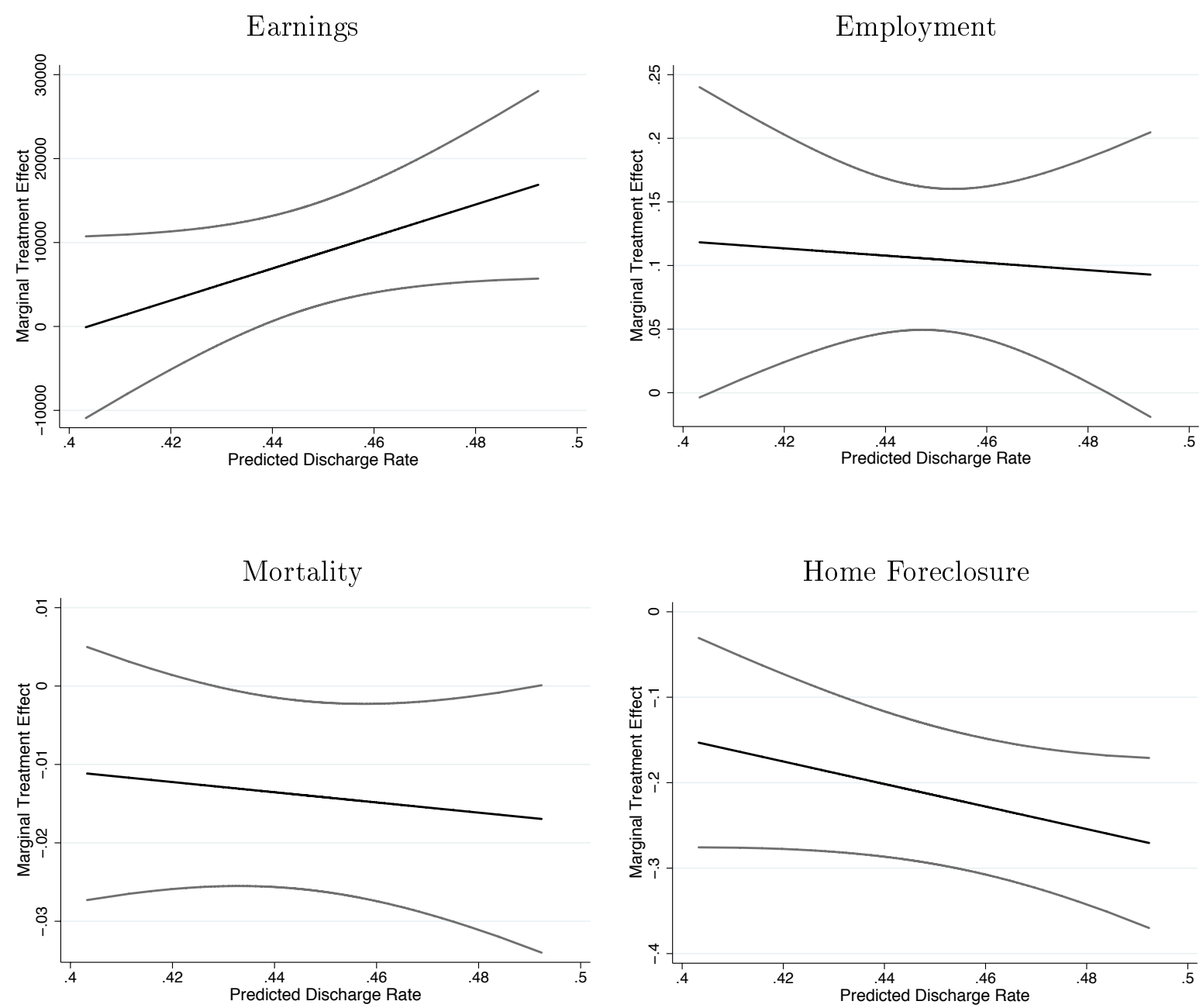

Notes: These figures plot marginal treatment effects and associated 95 percent confidence intervals. The sample includes first-time filings between 1992 and 2005 in the 42 offices that randomly assign cases to judges. The foreclosure sample includes the subset of those filings originating in county by year bins with foreclosure data coverage. We predict the probability of bankruptcy protection using our leave-one-out measure of judge leniency. We then predict the relationship between each outcome and the predicted probability of receiving bankruptcy protection using a local quadratic estimator with bandwidth 0.069 . The estimates of the first derivative of this relationship are then evaluated at each percentile of the predicted probability. Standard errors are calculated using a bootstrap procedure with 250 iterations. All monetary values are expressed in real 2000 dollars divided by 1,000. Earnings information comes from the W-2, and is averaged over the first five post-filing years. Employment is an indicator for non-zero wage earnings on the W-2, and is averaged over the first five post-filing years. Five-year mortality is an indicator for being deceased within the first five post-filing years using information from the Death Master File. Five-year foreclosure is an indicator for a filer's home receiving a notice of default, receiving a notice of transfer or sale, or being transferred to a REO or a guarantor within the first five post-filing years using real estate records from DataQuick. 
Appendix Figure 12

Marginal Treatment Effects for 401k Contributions, Disability Insurance, and Sup. Security Income


Notes: These figures plot marginal treatment effects and associated 95 percent confidence intervals. The sample includes first-time filings between 1992 and 2005 in the 42 offices that randomly assign cases to judges. See Appendix Figure $\mathrm{X}$ notes for details on estimation procedure and Table 1 notes for variable definitions. 
Appendix Figure 13

Job Mobility Marginal Treatment Effects
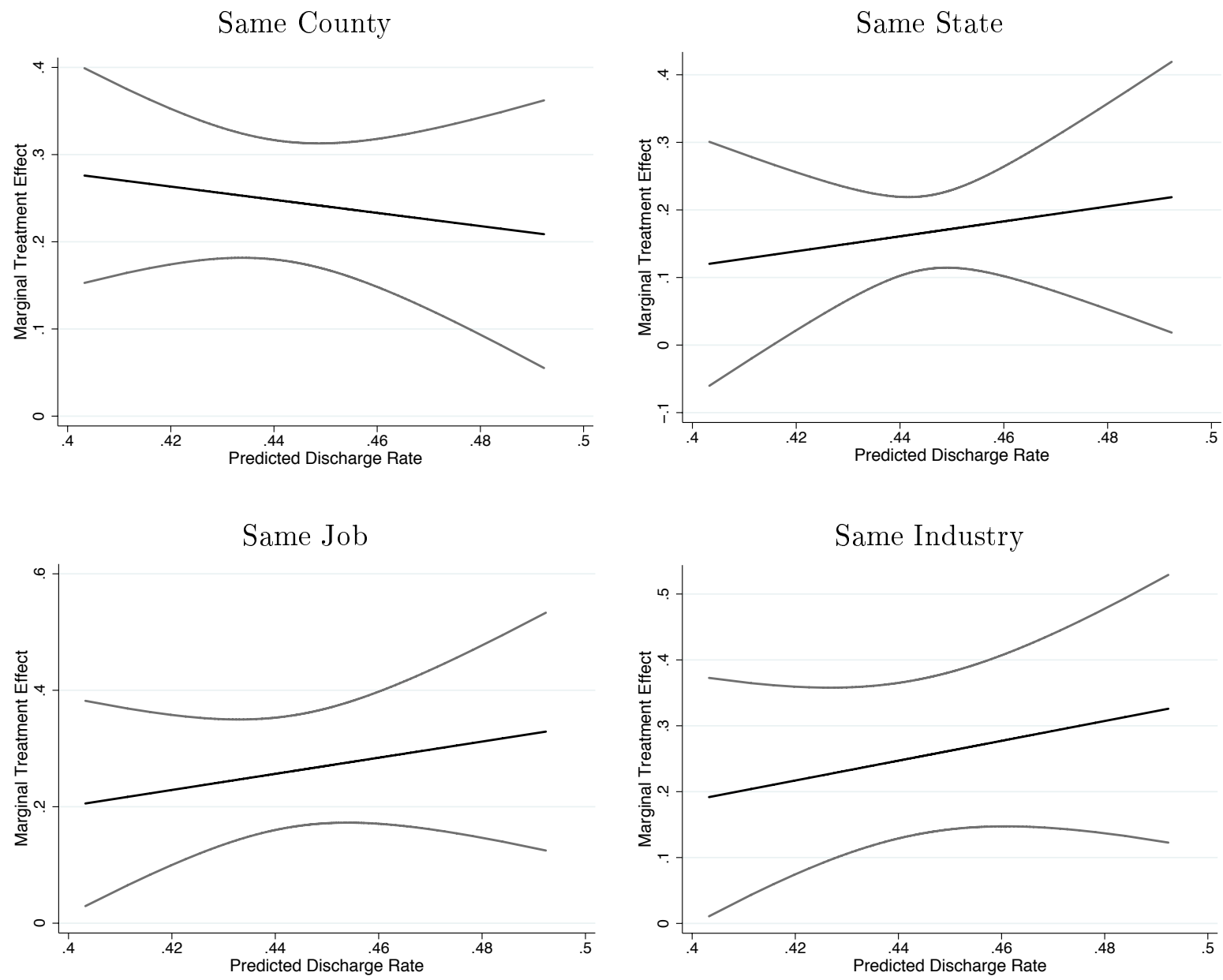

Job Tenure


Notes: These figures plot marginal treatment effects and associated 95 percent confidence intervals. The sample includes first-time filings between 1992 and 2005 in the 42 offices that randomly assign cases to judges. See Appendix Figure $\mathrm{X}$ notes for details on estimation procedure and Table 7 notes for variable definitions. 
Appendix Figure 14

Event Study Estimates of Chapter 13 and Chapter 7 Protection

Earnings

Ch. 13 Judge IV Sample

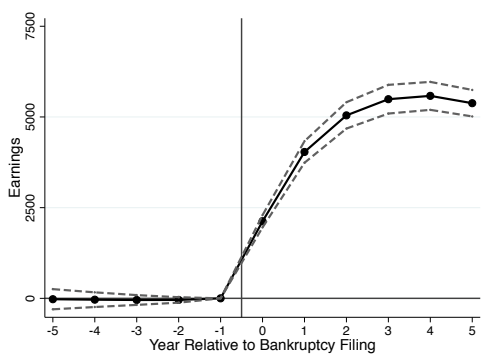

Employment

Ch. 13 Judge IV Sample

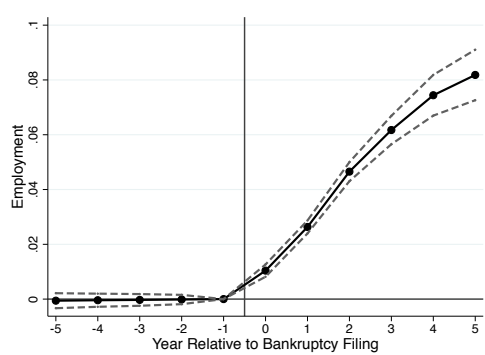

Mortality

Ch. 13 Judge IV Sample

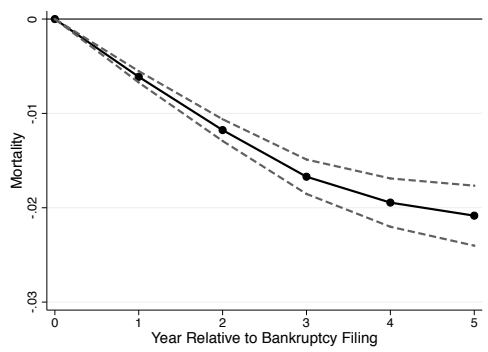

Home Foreclosure Ch. 13 Judge IV Sample

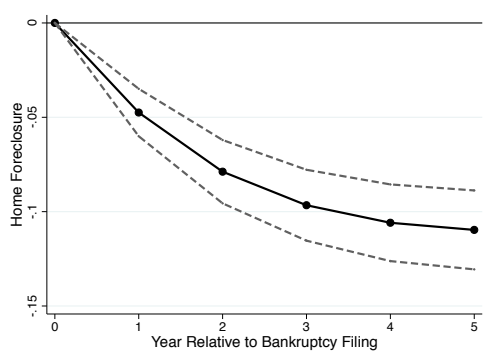

Earnings

Ch. 13 Full Sample

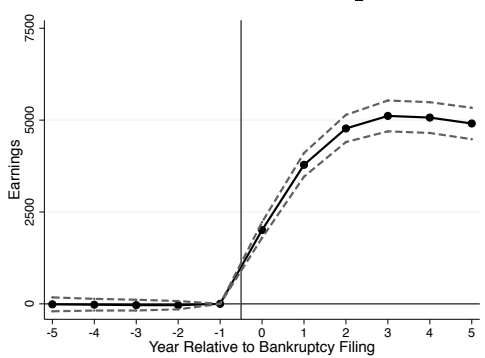

Employment

Ch. 13 Full Sample

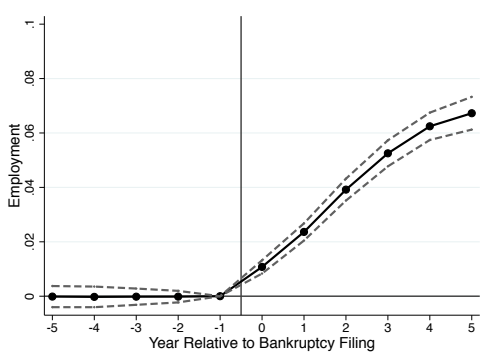

Mortality

Ch. 13 Full Sample

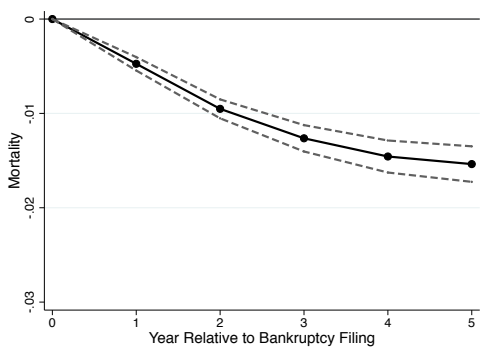

Home Foreclosure Ch. 13 Full Sample

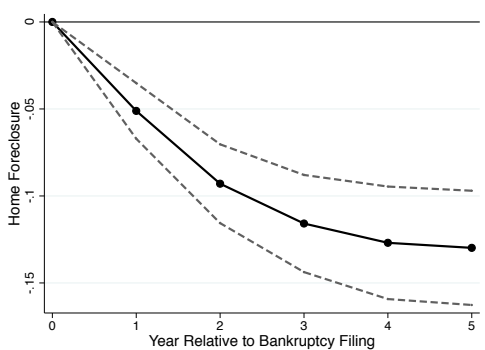

Earnings

Ch. 7 Full Sample

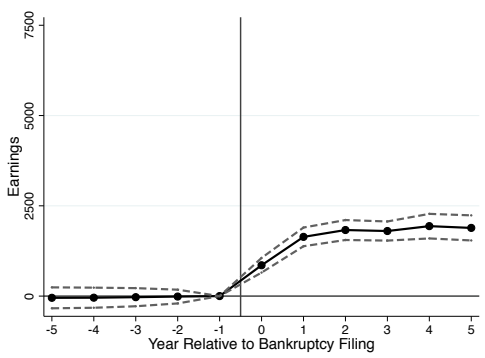

Employment

Ch. 7 Full Sample

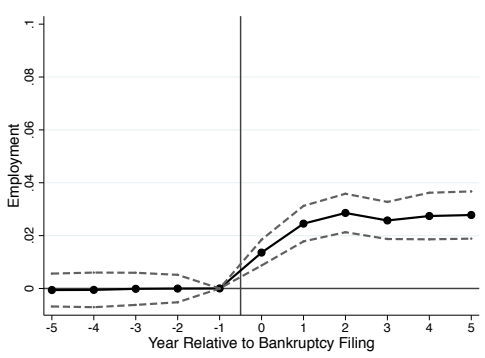

Mortality

Ch. 7 Full Sample

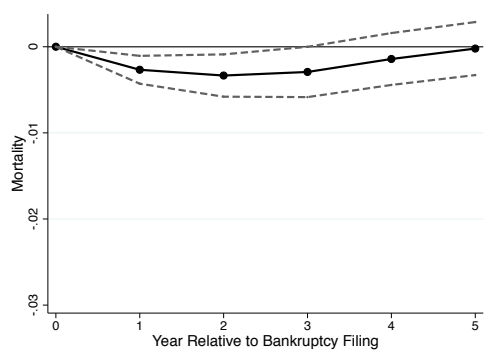

Home Foreclosure

Ch. 7 Full Sample

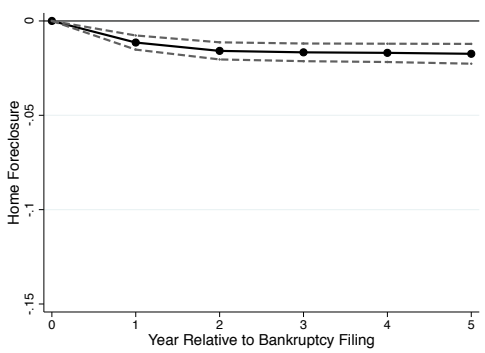


Appendix Figure 14 Continued

Event Study Estimates of Chapter 13 and Chapter 7 Protection

401k Contributions

Ch. 13 Judge IV Sample



Disability Insurance Ch. 13 Judge IV Sample

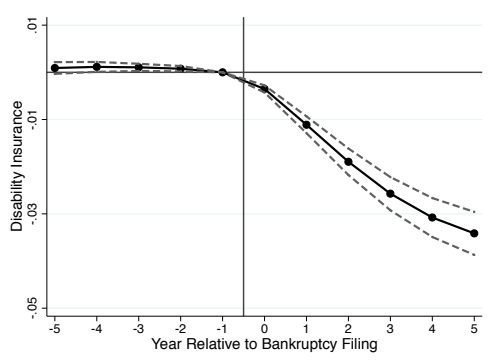

Sup. Security Income Ch. 13 Judge IV Sample

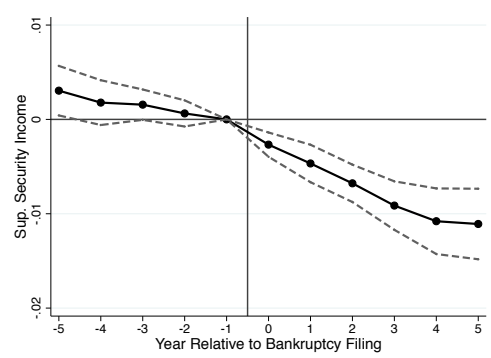

401k Contributions

Ch. 13 Full Sample

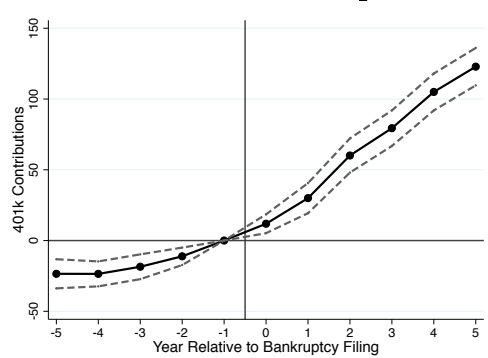

Disability Insurance

Ch. 13 Full Sample

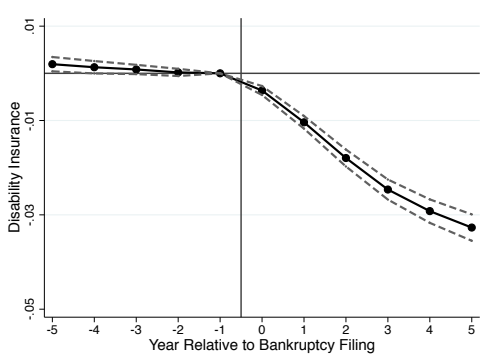

Sup. Security Income

Ch. 13 Full Sample

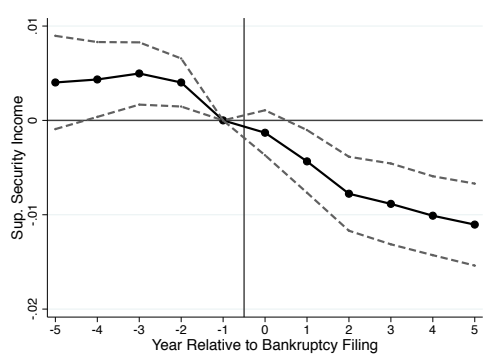

401k Contributions

Ch. 7 Full Sample

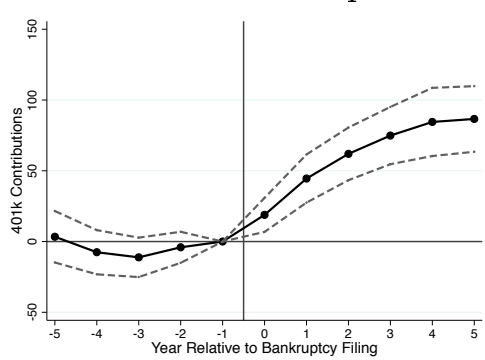

Disability Insurance

Ch. 7 Full Sample

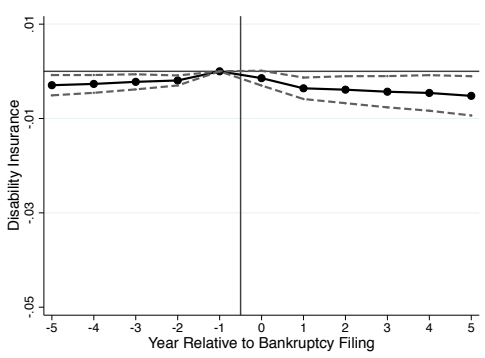

Sup. Security Income

Ch. 7 Full Sample

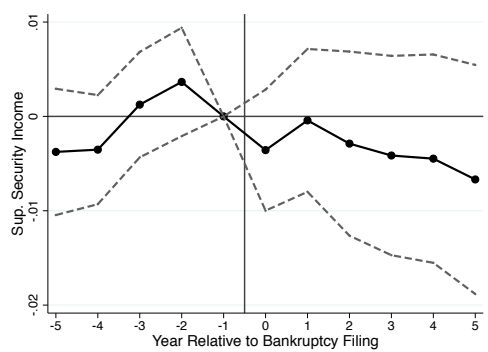


Notes: These figures plot event study results of the impact of Chapter 13 and Chapter 7 bankruptcy protection. The Judge IV sample includes all first-time filings between 1992 and 2005 in the 42 offices that randomly assign cases to judges. The full sample includes a 10 percent random sample of all first-time filings between 1992 and 2005 in the 72 bankruptcy courts that allow electronic access to their dockets. The foreclosure sample includes all filings originating in county by year bins with foreclosure data coverage. We report the coefficient on an indicator for receiving bankruptcy protection interacted with the specified year. We control for individual, year, and propensity score decile by year fixed effects. The propensity score is using a probit regression of an indicator for discharge on gender, race, five-year age bins, five years of baseline employment entered individually, five years of baseline earnings entered individually, office fixed effects, and filing year fixed effects. We then split the sample into deciles and interact each decile with year indicators for the five years before and after filing, omitting the year prior to filing. Standard errors are clustered at the individual level. Year 0 indicates the year a debtor files for bankruptcy protection. All monetary values are expressed in real 2000 dollars. Earnings information comes from the W-2. Employment is an indicator for non-zero wage earnings on the W-2. Mortality is an indicator for being deceased in the indicated year using information from the Death Master File. Foreclosure is an indicator for a filer's home receiving a notice of default, receiving a notice of transfer or sale, or being transferred to a REO or a guarantor. See text for additional details. 
Appendix Table 1

Bankruptcy Offices in Chapter 13 IV Sample

\begin{tabular}{|c|c|c|c|c|c|}
\hline Court & Office & Years & Judges & Discharge & $\sigma_{Z}$ \\
\hline Northern District of Alabama & Birmingham & $1999-2005$ & 3 & 0.312 & 0.032 \\
\hline Southern District of Alabama & Mobile & $2000-2005$ & 2 & 0.447 & 0.006 \\
\hline Eastern District of Arkansas & Little Rock & $1996-2001$ & 2 & 0.467 & 0.012 \\
\hline Southern District of California & San Diego & $1997-2005$ & 4 & 0.411 & 0.022 \\
\hline Southern District of Florida & Fort Lauderdale & $1994-2005$ & 2 & 0.335 & 0.019 \\
\hline Southern District of Florida & Miami & $1994-2005$ & 2 & 0.437 & 0.012 \\
\hline Northern District of Georgia & Atlanta & 2004-2005 & 8 & 0.296 & 0.035 \\
\hline Northern District of Georgia & Rome & $2004-2005$ & 2 & 0.401 & 0.011 \\
\hline Southern District of Iowa & Davenport & $1992-2001$ & 2 & 0.552 & 0.019 \\
\hline Southern District of Iowa & Des Moines & 1992-2001 & 2 & 0.608 & 0.042 \\
\hline District of Idaho & Boise & 1999-2005 & 2 & 0.519 & 0.022 \\
\hline Southern District of Indiana & Indianapolis & 2001-2005 & 3 & 0.495 & 0.015 \\
\hline Eastern District of Kentucky & Lexington & 1999-2005 & 2 & 0.585 & 0.033 \\
\hline District of Massachusetts & Boston & $1995-2003$ & 3 & 0.344 & 0.028 \\
\hline Eastern District of Michigan & Detroit & 2003-2005 & 3 & 0.291 & 0.007 \\
\hline Western District of Michigan & Grand Rapids & $1993-2005$ & 3 & 0.518 & 0.023 \\
\hline District of Minnesota & Minneapolis & $1992-2005$ & 2 & 0.462 & 0.009 \\
\hline District of Minnesota & St. Paul & $1992-2005$ & 2 & 0.485 & 0.030 \\
\hline Eastern District of Missouri & St. Louis & 2003-2005 & 2 & 0.405 & 0.015 \\
\hline Western District of Missouri & Kansas City & $2000-2005$ & 3 & 0.478 & 0.021 \\
\hline Middle District of North Carolina & Durham & 2005 & 2 & 0.558 & 0.017 \\
\hline District of New Mexico & Albuquerque & 1999-2005 & 2 & 0.315 & 0.024 \\
\hline District of Nevada & Las Vegas & $1996-2005$ & 2 & 0.396 & 0.010 \\
\hline Southern District of Ohio & Cincinnati & $1997-2005$ & 2 & 0.598 & 0.014 \\
\hline Southern District of Ohio & Columbus & $1992-2005$ & 3 & 0.573 & 0.049 \\
\hline Southern District of Ohio & Dayton & $1992-2005$ & 2 & 0.592 & 0.030 \\
\hline Northern District of Oklahoma & Tulsa & $1997-2005$ & 2 & 0.486 & 0.030 \\
\hline District of Oregon & Eugene & $1995-2005$ & 2 & 0.503 & 0.027 \\
\hline District & Portland & $2000-2005$ & 3 & 0.495 & 0.158 \\
\hline of South Carolina & Columbia & $2003-2005$ & 2 & 0.751 & 0.021 \\
\hline Eastern District of Tennessee & Chattanooga & $2002-2005$ & 2 & 0.424 & 0.017 \\
\hline istrict of Tennessee & Columbia & $2000-2005$ & 3 & 0.437 & 0.031 \\
\hline strict of Tennessee & Cookeville & $2000-2005$ & 3 & 0.437 & 0.047 \\
\hline nnessee & le & $2000-2005$ & 3 & 0.467 & 0.017 \\
\hline Western District of Tennessee & Memphis & $1997-2005$ & 3 & 0.277 & 0.007 \\
\hline Western District of Texas & San Antonio & $1997-2005$ & 2 & 0.452 & 0.010 \\
\hline District of Utah & Salt Lake City & $2003-2005$ & 3 & 0.334 & 0.019 \\
\hline Eastern District of Virginia & Alexandria & $2000-2005$ & 2 & 0.507 & 0.013 \\
\hline Eastern District of Virginia & Newport News & 1997-2005 & 2 & 0.523 & 0.035 \\
\hline Eastern District of Virginia & Norfolk & 1997-2005 & 2 & 0.551 & 0.021 \\
\hline Western District of Washington & Tacoma & $2000-2005$ & 2 & 0.503 & 0.017 \\
\hline Eastern District of Wisconsin & Milwaukee & 2003-2005 & 3 & 0.456 & 0.020 \\
\hline
\end{tabular}

Notes: This table presents descriptive statistics for the 42 offices in the 31 bankruptcy courts that randomly assign filings to judges in our instrumental variables sample. $\sigma_{Z}$ is the standard deviation of leave-one-out measure of judge leniency described in the text. 


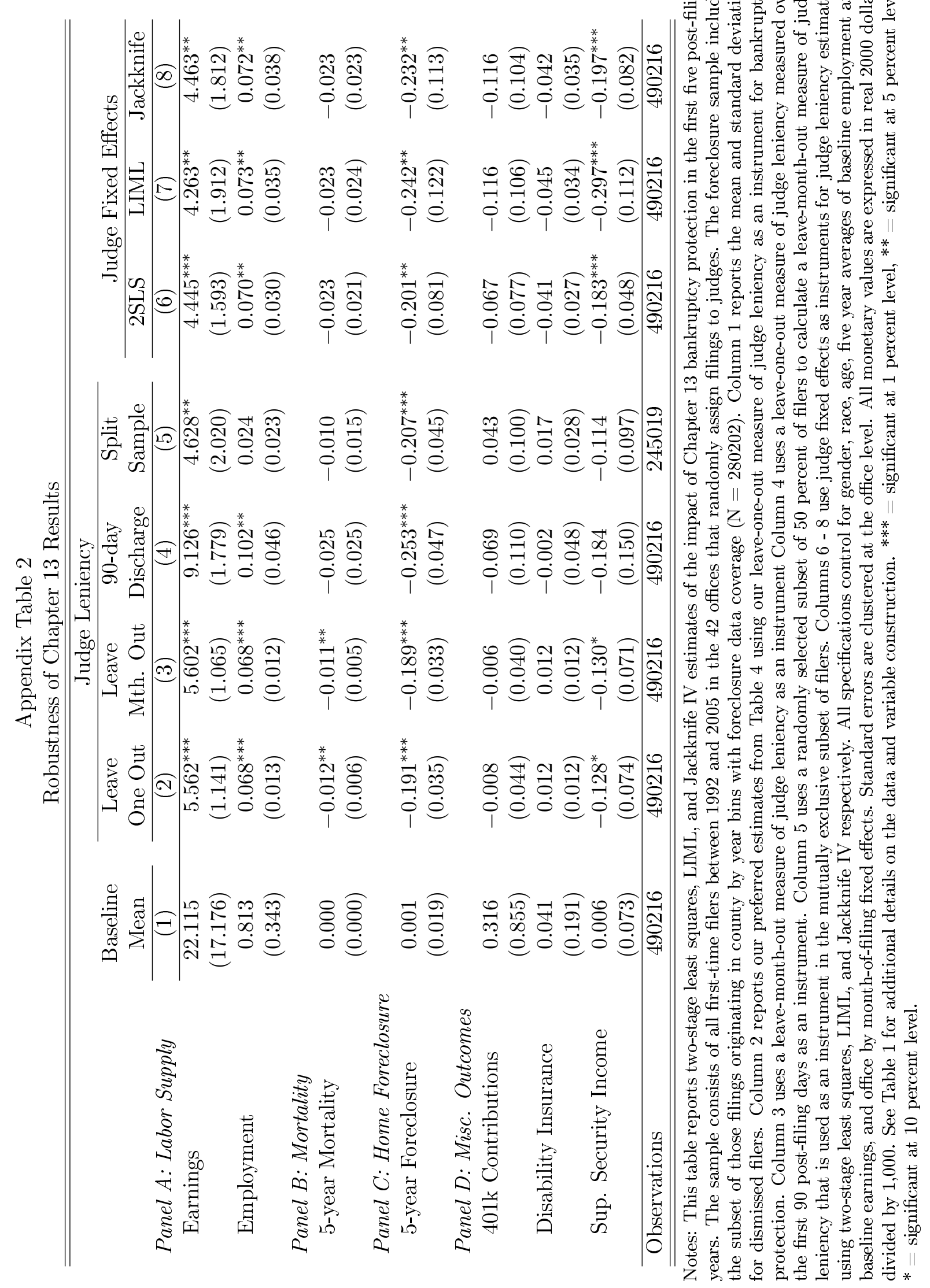


Appendix Table 3

Additional Tests of Randomization

\begin{tabular}{|c|c|c|c|c|}
\hline \multirow[b]{3}{*}{ Number of cases } & $\begin{array}{c}\text { Baseline } \\
\text { Mean }\end{array}$ & \multicolumn{2}{|c|}{ Judge Leniency } & $\begin{array}{c}\text { F-test } \\
\text { p-value }\end{array}$ \\
\hline & (1) & $(2)$ & $(3)$ & $(4)$ \\
\hline & $\begin{array}{l}1118.637 \\
(758.759)\end{array}$ & $\begin{array}{c}0.000012 \\
(0.000016\end{array}$ & & {$[0.000]$} \\
\hline Earnings Decile 2 & $\begin{array}{c}0.100 \\
(0.300)\end{array}$ & & $\begin{array}{c}-0.000444 \\
(0.000287)\end{array}$ & {$[0.557]$} \\
\hline Earnings Decile 3 & $\begin{array}{c}0.100 \\
(0.300)\end{array}$ & & $\begin{array}{r}-0.000193 \\
(0.000147)\end{array}$ & {$[0.474]$} \\
\hline Earnings Decile 4 & $\begin{array}{c}0.100 \\
(0.300)\end{array}$ & & $\begin{array}{r}-0.000221^{*} \\
(0.000129)\end{array}$ & {$[0.992]$} \\
\hline Earnings Decile 5 & $\begin{array}{c}0.100 \\
(0.300)\end{array}$ & & $\begin{array}{r}-0.000136 \\
(0.000137)\end{array}$ & {$[0.733]$} \\
\hline Earnings Decile 6 & $\begin{array}{c}0.100 \\
(0.300)\end{array}$ & & $\begin{array}{c}0.000084 \\
(0.000259)\end{array}$ & {$[0.285]$} \\
\hline Earnings Decile 7 & $\begin{array}{c}0.100 \\
(0.300)\end{array}$ & & $\begin{array}{c}0.000044 \\
(0.000143)\end{array}$ & {$[0.965]$} \\
\hline Earnings Decile 8 & $\begin{array}{c}0.100 \\
(0.300)\end{array}$ & & $\begin{array}{c}0.000078 \\
(0.000250)\end{array}$ & {$[0.813]$} \\
\hline Earnings Decile 9 & $\begin{array}{c}0.100 \\
(0.300)\end{array}$ & & $\begin{array}{c}0.000355 \\
(0.000350)\end{array}$ & {$[0.039]$} \\
\hline Earnings Decile 10 & $\begin{array}{c}0.100 \\
(0.300)\end{array}$ & & $\begin{array}{c}0.000147 \\
(0.000207)\end{array}$ & {$[0.312]$} \\
\hline Joint F-Test & & [0.468] & {$[0.288]$} & \\
\hline Observations & 490216 & 490216 & 490216 & \\
\hline
\end{tabular}

Notes: This table reports reduced form results testing the random assignment of filings to judges. The sample consists of all first-time Chapter 13 filers between 1992 and 2005 in the 42 offices that randomly assign filings to judges. Column 1 reports means and standard deviations for dismissed filers. Columns 2 - 3 report estimates from an OLS regression of judge leniency on the variables listed and office by month-of-filing fixed effects, with standard errors clustered at the office level. Judge leniency is the leave-one-out mean rate of granting bankruptcy protection for the assigned judge minus the leave-one-out mean rate of granting bankruptcy protection for the court in the same filing year. The p-value reported at bottom of columns $2-3$ is for a F-test of the joint significance of the variables listed in the rows. Each row of column 4 reports a p-value from a separate OLS regression of only the pre-determined variable listed in the corresponding row on judge and office by month-of-filing fixed effects. The p-value is for a F-test of the joint significance of the judge fixed effects. See Table 1 for details on the data and variable construction. *** $=$ significant at 1 percent level, ${ }^{* *}=$ significant at 5 percent level, $*=$ significant at 10 percent level. 


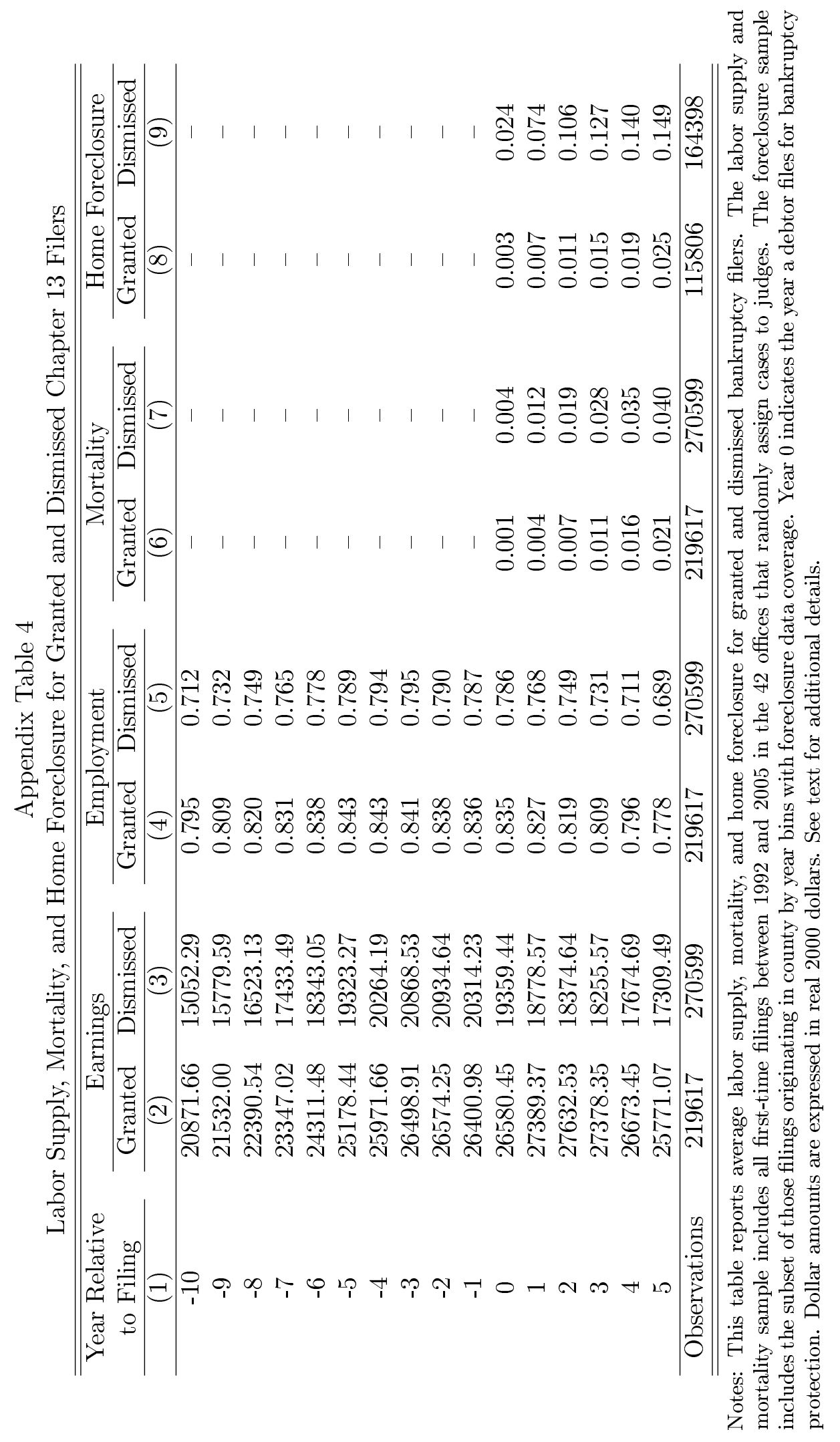


Appendix Table 5

Chapter 13 Results for Additional Outcomes

\begin{tabular}{ccccc}
\hline \hline & \multicolumn{2}{c}{ Baseline } & & \\
& Mean & & \multicolumn{2}{c}{ 2SLS Results } \\
\cline { 2 - 2 } \cline { 5 - 6 } Panel A: Labor Supply & $(1)$ & & $(2)$ & $(3)$ \\
\cline { 5 - 6 } Self Emp. Earnings & 0.585 & & 0.290 & 0.367 \\
& $(3.644)$ & & $(0.271)$ & $(0.299)$ \\
Self Employment & 0.061 & & -0.005 & 0.001 \\
& $(0.183)$ & & $(0.016)$ & $(0.018)$ \\
Earnings with no zeros & 23.729 & & $7.109^{* * *}$ & $4.416^{* * *}$ \\
& $(24.307)$ & & $(2.001)$ & $(1.636)$ \\
Panel B: Mortality & & & & \\
Years Alive (out of 5) & 5.000 & & $0.057^{* *}$ & $0.053^{* *}$ \\
& $(0.000)$ & & $(0.023)$ & $(0.021)$ \\
Panel C: Home Sales & & & \\
5-year Distress Sale & 0.001 & & $-0.221^{* * *}$ & $-0.222^{* * *}$ \\
& $(0.021)$ & & $(0.035)$ & $(0.036)$ \\
5-year Any Home Sale & 0.001 & & $-0.335^{* * *}$ & $-0.339^{* * *}$ \\
& $(0.031)$ & & $(0.046)$ & $(0.048)$ \\
\hline Controls & - & & No & Yes \\
Observations & 490216 & & 490216 & 490216 \\
\hline \hline
\end{tabular}

Notes: This table reports two-stage least squares results of the impact of Chapter 13 bankruptcy protection. The sample consists of all first-time filers between 1992 and 2005 in the 42 offices that randomly assign filings to judges. The home sample includes the subset of those filings originating in county by year bins with home sales data coverage $(\mathrm{N}=280202)$. Column 1 reports the mean and standard deviation for the five years before filing. Columns $2-3$ instrument for bankruptcy protection using the reduced form measure of judge leniency described in the text. All specifications control for office by month-of-filing fixed effects, and cluster standard errors at the office level. Column 3 adds controls for gender, race, age, and the five year average of baseline employment and baseline earnings. All monetary values are expressed in real 2000 dollars divided by 1,000. See Table 1 for additional details on the data and variable construction. ${ }^{* * *}=$ significant at 1 percent level, ${ }^{* *}=$ significant at 5 percent level, ${ }^{*}=$ significant at 10 percent level. 
Appendix Table 6

Chapter 13 Results for Years 6 - 10

\begin{tabular}{ccccc}
\hline \hline & \multicolumn{2}{c}{ Baseline } & & \\
& Mean & & \multicolumn{2}{c}{ 2SLS Results } \\
\cline { 2 - 2 } \cline { 5 - 6 } Panel A:Labor Supply & $(1)$ & & $(2)$ & $(3)$ \\
\cline { 2 - 3 } Earnings & 20.517 & & $8.127^{* * *}$ & $6.772^{* * *}$ \\
& $(16.147)$ & & $(1.949)$ & $(1.603)$ \\
Employment & 0.812 & & $0.096^{* * *}$ & $0.066^{*}$ \\
& $(0.340)$ & & $(0.029)$ & $(0.035)$ \\
Panel B: Mortality & & & & \\
10-year Mortality & 0.000 & & -0.026 & -0.015 \\
& $(0.000)$ & & $(0.024)$ & $(0.028)$ \\
Panel C: Home Foreclosure & & & \\
10-year Foreclosure & 0.000 & & $-0.272^{* * *}$ & $-0.277^{* * *}$ \\
& $(0.010)$ & & $(0.040)$ & $(0.042)$ \\
Panel D: Misc. Outcomes & & & \\
401k Contributions & 0.221 & & $0.405^{* * *}$ & $0.298^{* *}$ \\
& $(0.686)$ & & $(0.147)$ & $(0.140)$ \\
Disability Insurance & 0.033 & & $-0.054^{* * *}$ & $-0.034^{*}$ \\
Sup. Security Income & $(0.172)$ & & $(0.020)$ & $(0.020)$ \\
& 0.004 & & $-0.209^{* *}$ & $-0.156^{*}$ \\
& $(0.065)$ & & $(0.089)$ & $(0.088)$ \\
\hline Controls & - & & No & Yes \\
Observations & 189100 & 189100 & 189100 \\
\hline \hline
\end{tabular}

Notes: This table reports two-stage least squares results of the impact of Chapter 13 bankruptcy protection over the sixth through tenth post-filing years. The sample consists of all first-time filers between 1992 and 2000 in the 42 offices that randomly assign filings to judges. The foreclosure sample includes the subset of those filings originating in county by year bins with foreclosure data coverage $(\mathrm{N}=84181)$. Column 1 reports the mean and standard deviation for dismissed filers. Columns 2 - 3 instrument for bankruptcy protection using the reduced form measure of judge leniency described in the text. All specifications control for office by month-of-filing fixed effects, and cluster standard errors at the office level. Column 3 also includes controls for gender, race, age, and the five year average of baseline employment and baseline earnings. All monetary values are expressed in real 2000 dollars divided by 1,000. See Table 1 for additional details on the data and variable construction. ${ }^{* * *}=$ significant at 1 percent level, ${ }^{* *}=$ significant at 5 percent level, ${ }^{*}=$ significant at 10 percent level. 


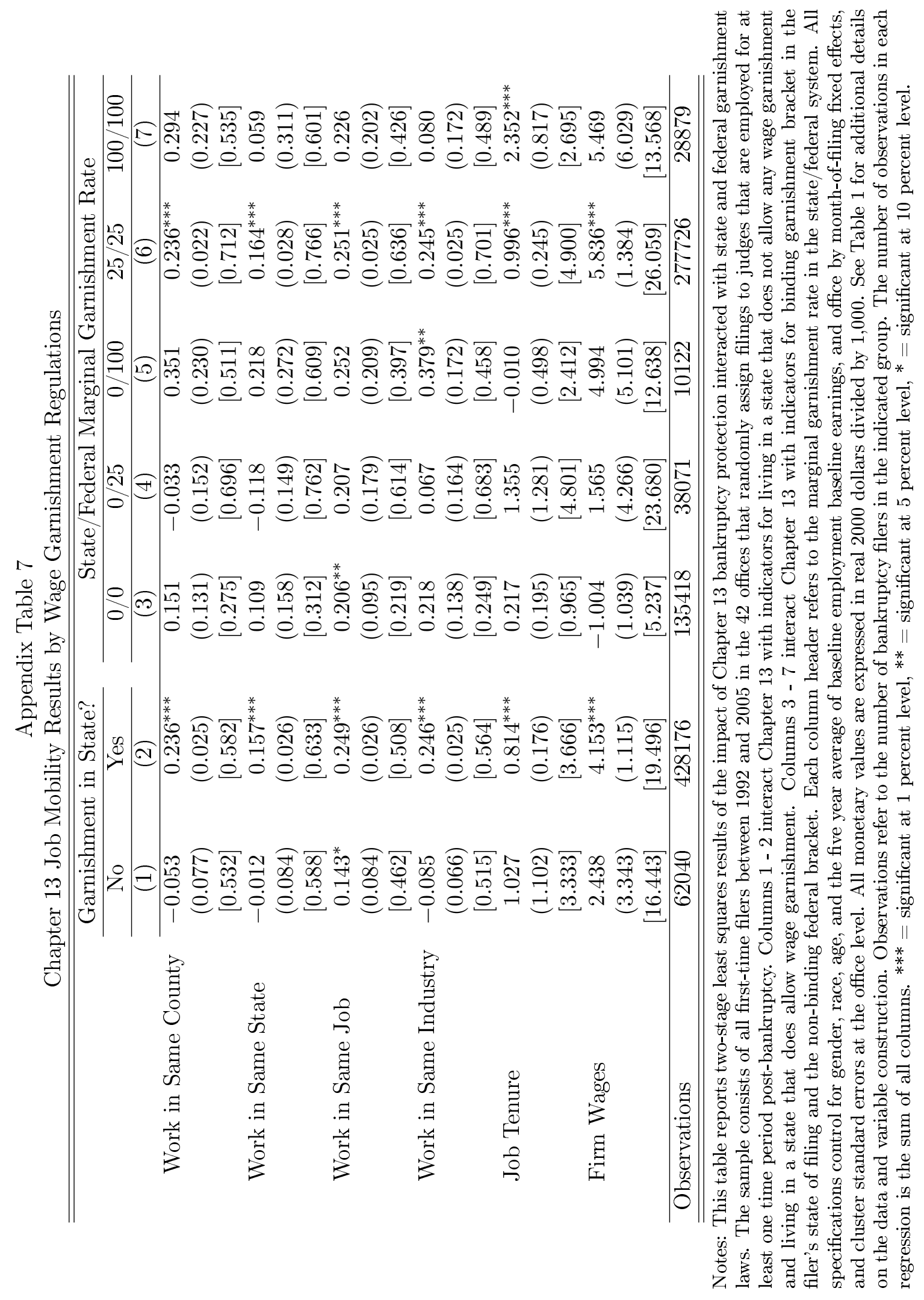

